\title{
JAMINAN DAN AGUNAN DALAM PEMBIAYAAN BANK SYARIAH DAN KREDIT BANK KONVENSIONAL
}

\section{Ifa Latifa Fitriani}

\author{
* Mahasiswi Program Magister Hukum Bisnis Syariah dan Peneliti Muda Hukum dan Syariah, Fakultas \\ Syari'ah dan Hukum UIN Sunan Kalijaga Yogyakarta \\ Korespondensi: ifalatifafitriani@yahoo.co.id \\ Naskah dikirim: 3 Oktober 2016 \\ Naskah diterima untuk diterbitkan: 15 Maret 2016
}

\begin{abstract}
Article 23 Clause(2) of Law Number 21 year 2008 about Islamic Banking expressly mentions the existence of both collateral and additional collateral. This law is different compared to Article 8 of Law Number 10 Year1998 about Banking which doesn't mention directly about requirement of collateral in its articles. That condition seems to indicate that there are shift norms in both of the laws. However, if we look into the collateral and additional collateral concept in conventional banking and Islamic banking, it has different fundamental background and principle. Collateral in conventional banking system appears due to the position and condition of the creditor-debitor relationship. The relationship has implicedto present the legal obligation of collateral things according to Article 1131 Book of Civil Law in every credit transaction. Islamic banking system has taken the consept of collateral from Rahn and kafalah, eventhough the reality shows the practice of collateral and additional collateral still using legal collateral norm of Indonesia's positive law sistem that based on Westren law.
\end{abstract}

Keywords: collateral, additional collateral, Islamic banking, conventional banking

\begin{abstract}
Abstrak
Pasal 23 Ayat (2)Undang-Undang Nomor 21 Tahun 2008 tentang Perbankan Syariah menyebutkan secara tegas keberadaan jaminan dan agunan. Hal ini berbeda jika melihat ketentuan Pasal 8 Undang-Undang Nomor10 Tahun 1998 tentang Perbankan, yang tidak menyebutkan ketentuan jaminan dan agunan tersebut dalam pasal. Hal ini berimplikasi ada pemaknaan seakan terjadi pergeseran antara kedua norma tersebut. Sedangkan jika melihat dalam konsepsi jaminan dan agunan perbankan konvensionaldan perbankan syariah memiliki dasar pemikiran yang berbeda. Jaminanan dan agunan dalam bank konvensional muncul dikarenakan adanya hubungan kreditur-debitur. Hubungan ini berimplikasi pada kewajiban hukum adanya jaminan dan agunan berdasarkan ketentuan Pasal 1131 Kitab Undang-Undang Hukum Perdata pada
\end{abstract}


setiap transaksi kredit. Sedangkan perbankan syariah melihat konsep jaminan dan agunan dari konsep Rahn dan Kafalah, meskipun dalam realitasnya praktik jaminan dan agunan bank syariah masih juga menggunakan norma hukum jaminan yang digunakan dalam sistem hukum positif Indonesia yang bersumber dari hukum Barat.

Kata kunci: jaminan, agunan, perbankan syariah, dan perbankan konvensional.

\section{A. Pendahuluan}

Perkembangan lembaga keuangan Islam mengalami perkembangan pesat di dunia melalui berbagai model legal framework of Islamic institution yang dipraktikan, baik di negara mayoritas maupun minoritas muslim seperti Inggris. Pada awal dipraktikannya sistem perbankan syariah di Indonesia, kondisi perbankan syariah yang tidak mengalami negative spread pasca krisis moneter tahun 1998, memunculkan keinginan Pemerintahan untuk mereformasi legalitas formal perbankan syariahmelalui diundangkannya UU No. 10 Tahun 1998 tentang Perubahan Atas UU No. 7 Tahun 1992 tentang Perbankan. Aturan ini mengatur bank yang beroperasi secara ganda (dual system bank), kemudian dilanjutkan dengan dibuatnya Arsitektur Perbankan Indonesia (API).

Tuntutan agar pengaturan tentang bank syariah di Indonesia lebih ditingkatkan mengakibatkan dikeluarkannya ketentuan UU No. 21 Tahun 2008 tentang Perbankan Syariah, yang memberikan legalitas kuat atas keberadaan perbankan syariah di Indonesia. Aturan ini merupakan kelanjutan dari policy yang dikeluarkan oleh Bank Indonesia, di mana Bank Indonesia pada tahun 2002 telah menerbitkan "Cetak Biru Pengembangan Bank Syariah di Indonesia". UU No. 21 Tahun 2008 memperkenalkan kegiatan usaha antara bank umum syariah (BUS), unit usaha syariah (UUS), dan Bank Pembiayaan Rakyat Syariah (BPRS).

Pasca berlakunya ketentuan UU No. 21 Tahun 2008 perubahan nyata terlihat dalam nomenklatur hukum yang mengatur ketentuan tentang perbankan syariah. Salah satunya yang terlihat nyata adalah keberadaan Agunan dalam pembiayaan bank syariah yang dinyatakan dalam ketentuan Pasal 23 Ayat (2) UU No. 21 Tahun 2008 berkaitan dengan pengaturan Kelayakan Penyaluran Dana. Berdasarkan pada ketentuan tersebut, dapat dilihat dalam praktik perbankan syariah sangat menitikberatkan keberadaan agunan dalam penilaian pemberian pembiayaan pada nasabah.

Ketentuan ini berbeda dengan penyebutan agunan dalam ketentuan Pasal 8 UU No. 10 Tahun 1998 yang tidak dinyatakan secara tegas dalam pasal tersebut, padahal jika merujuk pada Pasal 1131 KUHPerdata jelas menyebutkan seluruh hak kebendaan seseorang menjadi jaminan bagi seluruh perikatan. Ketentuan Pasal 8 UU No. 10 Tahun 1998 ini juga berbeda dengan ketentuan Pasal 24 Ayat (1) UU No. 14 tahun 1976 tentang Perbankan yang secara tegas menyebutkan keharusan pemberian jaminan dalam kredit. Jika melihat faktafakta tersebut, maka tulisan ini akan melihat apakah terjadi pergeseran 
kedudukan jaminan dan agunan dalam norma UU No. 21 Tahun 2008 dan UU No. 7 Tahun 1998, kemudian menjabarkan perbedaan antara jaminan dan agunan dalam konsepsi bank konvensional dengan bank syariah di Indonesia.

\section{B. Pembahasan}

1. Pembiayaan, Kredit, Agunan dan Jaminan dalam Hukum di Indonesia

UU No. 21 Tahun 2008 tentang Perbankan Syariah pada dasarnya tidak menggunakan istilah kredit sebagaimana yang digunakan dalam UU No. 10 Tahun 1998, tetapi menggunakan istilah pembiayaan sebagai padanan kata kredit dalam sistem lembaga keuangan syariah. Pembiayaan didefinisikan dalam Pasal 1 Angka 25 UU No. 21 Tahun 2008 tentang Perbankan Syariah sebagai:

Pembiayaan adalah penyediaan dana atau tagihan yang dipersamakan dengan itu berupa:

a. transaksi bagi hasil dalam bentuk mudharabah dan musyarakah;

b. transaksi sewa-menyewa dalam bentuk ijarah atau sewa beli dalam bentuk ijarah muntahiya bittamlik;

c. transaksi jual beli dalam bentuk hutang murabahah, salam, dan istishna';

d. transaksi pinjam meminjam dalam bentuk piutang qardh; dan

e. transaksi sewa-menyewa jasa dalam bentuk ijarah bntuk transaksi multijasa berdasarkan persetujuan atau kesepakatan antara Bank Syariah dan/atau UUS dan pihak lain yang mewajibkan pihak yang dibiayai dan/atau diberi fasilitas dana untuk mengembalikan dana tersebut setelah jangka waktu tertentu dengan imbalan ujrah, tanpa imbalan, atau bagi hasil.

Kata kredit pada dasar berasal dari bahasa Romawi Credere yang artinya percaya. ${ }^{1}$ Kredit dalam ketentuan Pasal 1 angka 11 UU No. 10 Tahun 1998 tentang Perbankandidefinisikan sebagai:

Kredit adalah penyediaan uang atau tagihan yang dapat dipersamakan dengan itu, berdasarkan persetujuan atau kesepakatan pinjam-meminjam antara bank dengan pihak lain yang mewajibkan pihak peminjam untuk melunasi utangnya setelah jangka waktu tertentu dengan pemberian bunga.

Perbedaan mendasar keduanya adalah jika return kredit melalui bunga, maka return pembiayaan dilakukan dengan cara-cara lain yang ditentukan sesuai dengan akad masing-masing pembiayaan syariah (berdasarkan prinsip bagi hasil, jual-beli, atau sewa menyewa). Sedangkan dalam hubungan nasabah

${ }^{1}$ A. Wangsawidjaja Z., Pembiayaan Bank Syariah, (Jakarta: Gramedia Pustaka Utama, 2012), hal. 152 . 
dan bank syariah berbentuk hubungan kemitraan, bukan hubungan debiturkreditur seperti dalam bank konvensional. ${ }^{2}$

Jaminan dan Agunan pada dasarnya merupakan dua istilah yang dapat saling dipertukarkan. Jaminan secara sederhana dimaknai sebagai tanggungan atas pinjaman yang diterima. ${ }^{3}$ Jaminan dalam nomenklatur hukum perdata di Indonesia ditemukan dalam Pasal 1131 KHUPer dan Penjelasan Pasal 8 UU No. 10 Tahun 1998 tentang Perbankan. Hanya saja, kedua peraturan tersebut tidak mendefinisikan secara jelas apa yang dimaksud dengan jaminan, kedua aturan ini menyatakan jaminan berkaitan erat dengam masalah utang piutang. Sehingga, Jaminan dapat didefinisikan sebagai suatu perjanjian antara kreditur dengan debitur, di mana debitur memperjanjikan sejumlah hartanya untuk kepentingan pelunasan utang menurut ketentuan peraturan yang berlaku, apabila dalam waktu yang telah ditentukan terjadi kemacetan pembayaran utang debitur. $^{4}$

Agunan dalam terminologi hukum perbankan didefinisikan dalam Pasal 1 angka 23 UU No. 10 Tahun 1998 tentang Perbankan sebagai suatu jaminan tambahan yang diserahkan Nasabah Debitur kepada Bank (Kreditur) dalam rangka pemberian fasilitas kredit atau pembiayaan berdasarkan Prinsip Syariah. Sedangkan Pasal 1 Angka 26 UU No. 21 Tahun 2008 tentan Perbankan Syariah menyebutkan Agunan merupakan jaminan tambahan, baik berupa benda bergerak maupun benda tidak bergerak yang diserahkan oleh pemilik Agunan kepada Bank Syariah dan/atau UUS, guna menjamin pelunasan kewajiban Nasabah Penerima Fasilitas.

Kedua aturan tersebut dengan tegas menyebutkan agunan sebagai jaminan tambahan, maka menurut Wangsawidjaja secara a contrario jika ada jaminan tambahan, tentulah ada jaminan pokok. Jika melihat terminologi hukum yang ada dalam UU No. 21 Tahun 2008, jaminan pokok pada dasarnya tidak disebutkan secara jelas. Namun jika merujuk pada istilah jaminan dan agunan dalam praktik perbankan yang dikemukan oleh A. Wangsawidjaja, bahwa istilah ini muncul dari SK No. 23/69/KEP/DIR tanggal 28 Februari 1991 tentang Jaminan Pemberian Kredit dan SE No. 23/6/UKU tanggal 28 Februari 1991 tentang Jaminan Pemberian Kredit. ${ }^{5}$ Pasal 1 huruf b dan c SK No. 23/69/KEP/DIR yang menyebutkan:

Jaminan pemberian kredit adalah keyakinan bank atas kesanggupan debitur untuk melunasi kredit sesuai dengan yang diperjanjikan.

${ }^{2}$ Muhammad Syafi'i Antonio, Bank Syariah: Dari Teori ke Praktik, (Jakarta: Gema Insani, 2001), hal. 34.

${ }^{3}$ A. Wangsawidjaja Z., Pembiayaan Bank Syariah, (Jakarta: Gramedia Pustaka Utama, 2012), hal. 285.

${ }^{4}$ Gatot Supramono, Perbankan dan Masalah Kredit: Suatu Tinjauan di Bidang Yuridis, (Jakarta: Renika Cipta, 2009), hal. 196. Jaminan dalam istilah fiqh diartikan sebagai suatu jenis perjanjian dengan cara memberikan barang yang dijadikan sebagai penguat kepercayaan dalam masalah hutang piutang. M. Abdul Mudjieb, Kamus Fiqh, (Jakarta: Pustaka Firasu, 1994), hal. 132.

${ }^{5}$ Wangsawidjaja Z, Pembiayaan Bank Syariah, (Jakarta: Gramedia Pustaka Utama, 2012), hal. 286. 
Agunan adalah jaminan material, surat berharga, garansi resiko yang disediakan oleh debitur untuk menanggung pembayaran kembali suatu kredit, apabila debitur tidak dapat melunasi kredit sesuai dengan yang diperjanjikan.

Ketentuan pada Pasal 23 ayat (1) UU No. 21 Tahun 2008 tentang Perbankan Syariah menyebutkan bahwa:

Bank Syariah dan/atau UUS harus mempunyai keyakinan atas kemauan dan kemampuan calon Nasabah Penerima Fasilitas untuk melunasi seluruh kewajiban pada waktunya, sebelum Bank Syariah dan/atau UUS menyalurkan dana kepada Nasabah Penerima Fasilitas.

Sedangkan dalam ketentuan Pasal 8 ayat (1) UU No. 10 Tahun 1998 tentang Perbankan hanya menyebutkan:

Dalam memberikan kredit atau pembiayaan berdasarkan Prinsip Syariah, Bank Umum wajib mempunyai keyakinan berdasarkan analisis yang mendalam atas itikad dan kemampuan serta kesanggupan Nasabah Debitur untuk melunasi utangnya atau mengembalikan pembiayaan dimaksud sesuai dengan yang diperjanjikan.

Jika dilihat ketiga ketentuan tersebut, A. Wangsawidjaja menambahkan jika ketentuan pengertian keyakinan sebagaimana yang dimaksud dalam dalam Pasal 23 ayat (1) UU No. 21 Tahun 2008 tentang Perbakan Syariah ini dikaitkan dengan ketentuan Pasal 1 huruf b dan c SK No. 23/69/KEP/DIR, maka dapat dianalogikan jika agunan adalah jaminan tambahan, maka 'keyakinan' bank untuk memberikan kredit dapat ditafsirkan secara a contrario pula sebagai jaminan pokok. ${ }^{6}$ Maka menurut pendapat penulis jika UU No. 21 Tahun 2008 merupakan lex sepecialis dari UU No. 10 Tahun 1998 sebagai lex generalis, maka pemaknaan/definisi dalam UU No. 10 Tahun 1998 tentang Agunan sebagai jaminan tambahan adalah sama dengan yang dimaknai dalam UU No. 21 Tahun 2008 tentang Perbankan Syariah. Dengan makna lain, jaminan pokok dalam UU No.107 Tahun 1998 adalah sama berkaitan dengan makna 'keyakiann' bank untuk memberikan kredit.

\section{Norma Jaminan dan Agunan dalam UU Perbankan dan UU Perbankan Syariah}

Jika diperhatikan lebih lanjut, pada dasarnya norma dalam UU No. 10 Tahun 1998 tentang Perbankan tidak menyebutkan secara spesifik kewajiban tersedianya jaminan atas kredit. Pasal 8 ayat (1) UU No. 10 Tahun 1998 tentang Perbankan hanya menyebutkan: 
Dalam memberikan kredit atau pembiayaan berdasarkan Prinsip Syariah, Bank Umum wajib mempunyai keyakinan berdasarkan analisis yang mendalam atas itikad dan kemampuan serta kesanggupan Nasabah Debitur untuk melunasi utangnya atau mengembalikan pembiayaan dimaksud sesuai dengan yang diperjanjikan.

Namun jika merujuk pada Penjelasan Pasal 8 UU Perbankan tersebut dikatakan:

Kredit atau pembiayaan berdasarkan Prinsip Syariah yang diberikan oleh bank mengandung risiko, sehingga dalam pelaksanaannya bank harus memperhatikan asas-asas perkreditan atau pembiayaan berdasarkan Prinsip Syariah yang sehat. Untuk mengurangi risiko tersebut, jaminan pemberian kredit atau pembiayaan berdasarkan Prinsip Syariah dalam arti keyakinan atas kemampuan dan kesanggupan Nasabah Debitur untuk melunasi kewajibannya sesuai dengan yang diperjanjikan merupakan faktor penting yang harus diperhatikan oleh bank. Untuk memperoleh keyakinan tersebut, sebelum memberikan kredit, bank harus belakukan penilaian yang seksama terhadap watak, kemampuan, modal, agunan, dan prospek usaha dari Nasabah Debitur. Mengingat bahwa agunan sebagai salah satu unsur pemberian kredit, maka apabila berdasarkan unsur-unsur lain telah dapat diperoleh keyakinan atas kemampuan Nasabah Debitur mengembalikan utangnya, agunan dapat hanya berupa barang, proyek, atau hak tagih yang dibiayai dengan kredit yang bersangkutan. Tanah yang kepemilikannya didasarkan pada hukum adat, yaitu tanah yang bukti kepemilikannya berupa girik, betuk, dan lain-lain yang sejenis dapat digunakan sebagai agunan. Bank tidak wajib meminta agunan berupa barang yang tidak berkaitan langsung dengan obyek yang dibiayai, yang lazim dikenal dengan agunan tambahan.

Ketentuan tersebut berbeda jika melihat ketentuan lama undang-undang perbankan. Pasal 24 ayat (1) UU No. 14 Tahun 1967 tentang Perbankan menyebutkan: "Bank Umum tidak memberikan kredit tanpa jaminan kepada siapapun juga". Pada perkembangan pengaturan norma agunan dalam pembiayaan perbankan syari'ah, secara tegas disebutkan dalam Bagian Kelayakan Penyaluran Dana Pasal 23 ayat (2) UU Perbankan Syariah disebutkan bahwa:

Untuk memperoleh keyakinan sebagaimana dimaksud pada ayat (1), Bank Syariah dan/atau UUS wajib melakukan penilaian yang saksama terhadap watak, kemampuan, modal, Agunan, dan prosepek usaha dari calon Nasabah Penerima Fasilitas.

Penjelasan Pasal 23 ayat (2) UU Perbankan Syariah menyebutkan: 
Dalam melaksanakan penilain terhadap Agunan, Bank syariah dan/atau UUS harus menilai barang, proyek atau hak tagih yang dibiayai dengan fasilitas Pembiayaan yang bersangkutan dan barang lain, surat berharga atau gransi risiko yang ditambahkan sebagai Agunan tambahan, apakah sudah cukup memadai, sehingga apabila Nasabah Penerima Fasilitas kelak tidak dapat melunai kewajibannya, Agunan tersebut dapat digunakan untuk menanggung pembayaran kembali pembiayaan dari Bank Syariah dan/atau UUS yang bersangkutan.

Sedangkan dalam ketentuan Pasal 1131 KUHPerdata dengan tegas disebutkan:

Segala hak kebendaan debitur baik yang bergerak maupun yang tidak bergerak, baik yang sudah ada maupun yang akan ada di kemudian hari menjadi tanggungan untuk segala perikatannya.

Perbedaan keberadaan agunan dalam norma peraturan perundanganundangan perbankan di Indonesia, di mana dalam UU No. 7 Tahun 1998 tentang Perbankan pada dasarnya tidak disebutkan adanya kewajiban adanya Agunan pada pemberian Kredit dan Pembiayaan. Namun, Penjelasan Pasal 8 UU No. 10 Tahun 1998 tersebut jelas menunjukan adanya penekanan pada faktor penting adanya jaminan, dimana jaminan ini direalisasikan dengan agunan pokok dan agunan tambahan. Sejalan dengan ketentuan Pasal 1131 KUHPer ini telah diwajibkan adanya jaminan pada setiap kredit, di mana jaminan ini timbul dari undang-undang.

Sehingga jika melihat penjelasan Pasal 8 UU No. 7 Tahun 1998 tentang Perbankan bahwa untuk menilai kelayakan pemberian kredit/pembiayaan kepada calon debiturnya, maka bank harus menerapkan prinsip The Five C's $O f$ Credit Analysis (5C) antara lain Character, Capital, Capacity, Collateral dan Condition of Economy. ${ }^{7}$ Pada sasarannya konsep $5 \mathrm{C}$ ini akan dapat memberikan informasi mengenai itikad baik (willingness to pay) dan kemampuan membayar (ability to pay) nasabah untuk melunasi kembali pinjaman beserta bunganya. ${ }^{8}$ Berbeda dengan pembiayaan dalam bank syariah yang secara tegas disebutkan tentang adanya Agunan dalam UU No. 21 Tahun 2008 tentang Perbankan Syariah.

Pertanyaan yang kemudian timbul adalah apakah terjadi pergeseran norma tentang Agunan yang dinyatakan secara tegas dalam undang-undang $a$ quo perbankan syariah di Indonesia saat ini, atau apakah pembiayaan di bank syariah memang mengadopsi konsep perjanjian kredit sebagaimana yang dipahami dalam konsepsi hukum privat positif di Indonesia.

7 Ni Made Trisna Dewi, "Tanggung Jawab Debitur Terhadap Musnahnya Benda Jaminan Fidusia dalam Perjanjian Kredit Bank", Tesis, Program Pascasarjana Universitas Udayana, Denpasar, 2011, hal. 49-51.

${ }^{8}$ Achmadi Usman, Aspek-Aspek Hukum Perbankan di Indonesia, (PT. Gramedia Pustaka Utama: Jakarta, 2001), hal. 246. 
Untuk menjawab pertanyaan tersebut, secara tegas penulis dapat secara parsial mengakui adanya pergeseran norma di mana Agunan telah secara tegas disebutkan sebagai Bagian Kelayakan Penyaluran Dana sebagaimana diatur dalam Pasal 23 ayat (2) UU No. 21 Tahun 2008 tentang Perbankan Syariah. ${ }^{9}$ Berbeda dengan ketentuan Pasal 8 UU No. 10 Tahun 1998 tentang Perbankan yang tidak menyatakan secara tegas dalam ketentuan pasal, tetapi dijabarkan dalam Penjelasan Pasal 8 UU No. 10 Tahun 1998 tentang Perbankan.

Suatu peraturan perundang-undangan baik yang merujuk pada TAP MPR No. XX/MPRS/1966, TAP MPR No. III/MPR/2000, UU No. 10 Tahun 2004 hingga UU No. 12 Tahun 2011 tentang Pembentukan Peraturan PerundanganUndangan, umumnya menggunakan Penjelasan "memorie van toelichting". Penjelasan ini berfungsi untuk membantu si pemakai peraturan perundangundangan dengan mudah mengetahui latar belakang dibentuknya suatu peraturan, tujuan pembentukannya, memahami isi dari pasal-pasal yang telah diundangkan. ${ }^{10}$

Menurut pandangan penulis, Pasal 8 UU No. 10 Tahun 1998 ini telah diinterpretasi secara tegas dalam Penjelasan, ${ }^{11}$ sehingga pada praktik rujukan untuk melaksanakan ketentuan dalam batang tubuh pasal dilihat dalam penjelasan dari frasa yang dimaksud, sebagaimana jika merujuk pada UU No. 10 Tahun 2004 tentang Pembentukan Peraturan Perundang-Undangan, dalam Lampiran angka 149 disebutkan bahwa: ${ }^{12}$

Penjelasan berfungsi sebagai tafsiran resmi pembentukan peraturan perundang-undangam atas norma tertentu dalam batang tubuh. Oleh karena itu, penjelasan hanya memuat uraian atau jabaran lebih lanjut dari norma yang diatur dalam batang tubuh. Dengan demikian, penjelasan sebagai sarana untuk memperjelas norma dalam batang tubuh tidak boleh mengakibatkan terjadinya ketidakjelasan dari norma yang dijelaskan.

9 Lihat Dr. Agus Pandomo, SH., Mkn, "Diktat Kuliah: Sistem Hukum Lembaga Keuangan Konvensional Bank dan Non Bank Jilid I”, Program Studi Hukum Bisnis Syariah, UIN Sunan Kalijaga Yogyakarta Tahun 2016, hlm. 21.

${ }^{10}$ Soehino, Hukum Tatanegara: Teknik Perundang-Undangan, (Yogyakarta: Liberty, 1996), hal. 123.

11 Baik jika dilihat dari interpretasi restriktif, dan argumentasi a contrario dari ketentuan Pasal 8 UU No. 10 Tahun 1998 ini dikaitkan dengan interpretasi gramatikal dalam Penjelasan sebagai tafsiran utama suatu pasal. Secara tegas dapat dimaknai bahwa ketentuan Pasal 8 ini ditegaskan dalam pejelasan, sehingga muncul interpretasi restriktif pada Pasal 8 tidak dapat keluar dari Pejelasan Pasal 8 tersebut. Maka, kenyataan praktik hukum yang terjadi adalah, agunan dimaknai sebagai jaminan tambahan, argumentasi a contrario-nya keyakinan kemampuan ini sebagai jaminan pokok, menajadi faktor utama pada saat Bank akan memberikan kredit kepada nasabah.

12 Lampiran dalam UU No. 12 Tahun 2011 tentang Pembentukan Peraturan Perundangan-Undangan pun masih menjelaskan kedudukan Penjelasan dalam pemaknaan yang sama. Dalam Lampiran I angka 176 UU No. 12 Tahun 2011 ditegaskan oleh karena itu, penjelasan hanya memuat uraian terhadap kata, frasa, kalimat atau padanan kata/istilah asing dalam norma yang dapat disertai dengan contoh. Pejelasan sebagai sarana untuk memperjelas norma dalam batang tubuh tidak boleh mengakibatkan terjadinya ketidakjelasan dari norma yang dimaksud. Lihat lebih lanjut metode penemuan hukum dalam Sudikno Mertokusumo, Penemuan Hukum: Sebuah Pengantar, (Yogyakarta: Liberty, 2004), hal.57-70. 
Dengan demikian dapat dimaknai bahwa keharusan adanya jaminan dalam UU No. 10 Tahun 1998 adalah tersirat dalam "keyakinan berdasarkan analisis yang mendalam atas itikad dan kemampuan serta kesanggupan nasabah debitur....", yang mana ketentuan ini mencerminkan the colleteral of creadit, dalam dunia praktik bisnis perbankan umumnya didefinisikan sebagai jaminan/agunan. ${ }^{13}$ Penjelasan Pasal 8 UU No. 10 Tahun 1998 dengan jelas menunjukan adanya kewajiban jaminan khusus, ${ }^{14}$ di samping jaminan umum yang timbul dari undang-undang (Pasal 1135 KUHPer).

Jaminan Khusus ini diuraikan dalam penjelasan dengan Agunan, sebagai jaminan tambahan, di mana dalam penjelasannya dapat dimaknai agunan pokok menjadi jaminan jika keyakinan kepada nasabah telah terpenuhi, sedangkan bank tidak wajib meminta agunan tambahan. Berdasarkan penjabaran di atas, dalam pandangan penulis, ketentuan dalam Pasal 8 UU No. 10 Tahun 1998 tentang Perbankan pada dasarnya menunjukan ketidakjelasan jika dikaitkan dengan keharusan (wajib) adanya jaminan berdasarkan Pasal 1135 KUHPer, baik jaminan pokok maupun jaminan tambahan. Hal ini berbeda dengan Pasal 23 UU No. 21 Tahun 2008 tentang Perbankan Syariah yang lebih tegas menyebutkan adanya jaminan, sehingga implikasi pada praktik yang terjadi tidak membingungkan di masyarakat mengingat dasar hukumnya yang jelas.

\section{Jaminan/Agunan dalam Perjanjian Kredit Bank Konvensional dan Pembiayaan Bank Syariah}

Ditelaah lebih lanjut pada dasar teoritisnya, perikatan perjanjian kredit didasari pada perjanjian pinjam meminjam, sebagaimana pernyataan Subekti yang menyebutkan bahwa segala macam pemberian kredit itu pada hakikatnya merupakan suatu perjanjian pinjam peminjam sebagaiman diatur dalam Pasal 1754 s/d Pasal 1769 KUHPer. ${ }^{15}$ Sedangkan pendapat lain sebagaimana dikemukan oleh Mariam Darus Badrulzaman dan Djuhaendah Hasan, bahwa pada dasarnya perjanjian kredit memilik identitas yang berbeda dengan perjanjian pinjam meminjam atau perjanjian pinjam uang. Salah satu identitasnya yang berkaitan dengan adanya jaminan, yakni pemaknaan perjanjian kredit bank harus mempunyai keyakinan atas kemampuan debitur dalam pengembalian kredit, di mana hal ini diformulasikan dalam bentuk jaminan baik berupa materiil maupun immateril. ${ }^{16}$

13 Lihat Dr. Agus Pandomo, SH., Mkn, "Diktat Kuliah: Sistem Hukum Lembaga Keuangan Konvensional Bank dan Non Bank Jilid II”, Program Studi Hukum Bisnis Syariah, UIN Sunan Kalijaga Yogyakarta Tahun 2016, hal. 63

${ }^{14}$ Lihat lebih lanjut dalam Gatot Supramono, , Perbankan dan Masalah Kredit: Suatu Tinjauan di Bidang Yuridis, (Jakarta: Renika Cipta, 2009). 196-200.

${ }^{15}$ Subketi dalam Indah Antari Murti, "Perjanjian Kredit dengan Jaminan Fidusia Atas Kendaraan Bermotor Yang Dijual Pada Pihak Ketiga Pada PT. Bank Danamon (Persero) Tbk Unit DSP Pracimantoro Wonogiri”, Tesis, Program Studi Magister Kenotariatan, Universita Diponogoro Semarang, 2010, hal. 46.

16 Perjanjian kredit dilihat dari peruntukannya spesifik; diberikan oleh Lembaga Keuangan; perjanjian tidak merujuk pada Buku III dan Bab II KUHPer sebagaimana perjanjian pinjam meminjam; ada keharusan pengembalin pinjam harus disertai bunga, imbalan, atau bagi 
Pada praktiknya, bank harus melakukan analisis pemberian kredit agar terhindar dari potensi menjadi kredit macet. Kredit bank mengandung resiko, sehingga dalam pelaksanaanya bank harus memperhatikan asas-asas perkreditan yang sehat. Asas-asas perkreditan yang sehat ini di antaranya: ${ }^{17}$

a. Bank tidak dapat diperkenankan untuk memberikan kredit tanpa adanya suatu perjanjian tertulis.

b. Bank tidak dapat diperkenankan untuk memberikan kredit pada usaha yang sejak semula telah diperhitungkan kurang sehat dan akan membawa kerugian.

c. Bank tidak dapat diperkenankan untuk memberikan kredit untuk pembelian saham dan modal kerja dalam rangka kegiatan jual beli saham.

d. Bank tidak dapat diperkenankan untuk memberikan kredit melampaui batas maksimum pemberian kredit (legal lending limit)

Dengan pemaknaan demikian pula, dapat dipahami bahwa Agunan (jaminan kredit) ini merupakan jenis perjanjian accesoir yang mengikuti perjanjian pokok, dimana hal ini merupakan bagian dari realisasi prinsip kredit melalui Collateral, serta berimplikasi pada status krediturnya sebagai kreditur sparatis yakni kreditur pemegang jaminan kebendaan. ${ }^{18}$

Dalam praktik perbankan, jaminan ini diartikan secara luas meliputi agunan dan penanggungan baik bersifat perorangan maupun jaminan perusahaan. Jaminan secara sempit hanya agunan saja, yang meliputi benda bergerak dan tidak bergerak, sedangkan agunan pokok adalah barang, proyek, atau hak tagih yang dibiayai dengan fasilitas pembiayaan, dan agunan tambahan merupakan barang-barang lain yang tidak dibiayai dengan fasilitas pembiayaan. ${ }^{19}$ Jaminan dalam konsepsi ekonomi Islam ini dilahirkan dari konsep al-rahn (gadai) ${ }^{20}$ dan kafalah $^{21}$ di mana ditafsirkan dari dalil Naqli dalam al-Qur'an dan Hadis. Dalam Al Qur'an surat Al-Baqarah ayat 283 dan Yusuf ayat 72 ditegaskan:

"Jika kamu dalam perjalanan (dan bermu'amalah tidak secara tunai) sedang kamu tidak memperoleh seorang penulis, maka hendaklah ada

hasil; dan perjanjian kredit bank harus mempunyai keyakinan atas kemampuan debitur dalam pengembalian kredit, di mana hal ini diformulasikan dalam bentuk jaminan baik berupa materiil maupun immateril; perjanjian kredit bank mempunyai sifat konsensual berbeda dengan perjanjian pinjam-meminjam uang yang bersifat riil. Dikutip dalam Ibid., hal. 46-47.

${ }^{17}$ Ibid., hal. 50.

${ }^{18}$ Terhadap jaminan ini akan timbul masalah manakala seorang debitur memiliki lebih dari seorang kreditur di mana masing-masing kreditur menginginkan haknya didahulukan. Kreditur dengan hak tanggungan ini diberikan kekuasaan atas jaminan kepada diberikan oleh hukum hak mengeksekusi. Lihat lebih lanjut dalam Munir Fuadi, Hukum Jaminan Hutang, (Jakarta: Erlangga, 2013), hal. 95.

${ }^{19}$ Wangsawidjaja Z., Pembiayaan Bank Syariah, (Jakarta: Gramedia Pustaka Utama, 2012), hal. 288.

${ }^{20}$ Ayat lain seperti tafsiran dalam Al-Maidah ayat (1), Al-Isra ayat 34, dan beberapa hadis Nabi. Lihat lebih lanjut dalam Hendi Suhendi, Fiqh Muamalah, (Jakarta: RajaGrafindo Persada, 2014), hal. 105-107.

${ }^{21}$ Lihat Fatwa DSN No. 11/DSN-MUI/VI/2000 tentang Kafalah, dan Fatwa DSN No. 74/DSN-MUI/I/2009 tentang Penjaminan Syariah. 
barang tanggungan yang dipegang (oleh yang berpiutang). Akan tetapi jika sebagian kamu mempercayai sebagian yang lain, maka hendaklah yang dipercayai itu menunaikan amanatnya (hutangnya) dan hendaklah ia bertakwa kepada Allah Tuhannya; dan janganlah kamu (para saksi) menyembunyikan persaksian. Dan barangsiapa yang menyembunyikannya, maka sesungguhnya ia adalah orang yang berdosa hatinya; dan Allah Maha Mengetahui apa yang kamu kerjakan"

"Penyeru-penyeru itu berkata: "Kami kehilangan piala raja, dan siapa yang dapat mengembalikannya akan memperoleh bahan makanan (seberat) beban unta, dan aku menjamin terhadapnya"

Jaminan dalam praktik lembaga keuangan syariah berlandaskan pada Fatwa DSN No. 68/DSN-MUI/III/2008 tentang Rahn Tasjily ${ }^{22}$ diperbolehkan adanya jaminan barang. Dalam perkembangannya, Fatwa DSN No. 92/DSNMUI/IV/2014 tentang Pembiayaan yang Disertai Rahn (Al-Tamwil Al-Mautsuq Bi Al-Rahn) menegaskan adanya kebolehan penggunana agunan pada pembiayaan/penyaluran dana pada lembaga keuangan syariah. Ketika muncul perdebatan apakah boleh atau tidak agunan digunakan sebagai salah satu dasar pertimbangan pembiayaan atau hutang dalam Bank Syariah, bahkan telah menjadi hal yang diwajibkan bagi nasabah penerima fasilitas bank syariah (meskipun hal ini menjadi perdebatan adanya agunan dalam pembiayaan mudharabah dan musyarakah, yang dianggap tidak mengharuskan adanya jaminan), maka pada dasarnya DSN MUI sebagai sole interpretor of islamic economy di Indonesia saat ini telah menafsirkan kebolehan praktik tersebut berdasarkan kedua fatwa yang dikeluarkan.

Kebolehan yang kemudian dalam praktik menjadi kewajiban sebagai dasar pemberian fasilitas dalam bank syariah ini menurut pandangan penulis bukan dikarenakan Islam mengadopsi prinsip kedudukan kreditur-debitur sebagaimana dimaknai dalam hukum perikatan. Kebolehan dalam praktik bank syariah ini lebih pada kesadaraan akan resiko munculnya moralhazard di samping melihat praktik dan tafsiran atas dalil-dalil naqlidalam konsep rahn dan kafalah tersebut di atas.

Jika dilihat dalam kajian teoritis atas kebaradaan jaminan tersebut, pada prinsipnya dapat merujuk pada Hasbi as-Shiddiqi menjelaskan bahwa hukum Islam bisa berubah menurut situasi dan kondisi, sebagaimana kaidah fiqh "taghayyiru al-ahkam bi taghayyiru al-azman wa al-amkan".Menurut beliau,

\footnotetext{
${ }^{22}$ Rahn tasjily adalah jaminan dalam bentuk barang atas utang tetapi barang jaminan tersebut (marhum) tetap berada dalam penguasaan (pemanfaatan) rahin atau nasabah penerima fasilitas (Debitur) seabgai pihak yang menyerahkan barang jaminan, dan bukti kepemilikan barang jaminan tersebut diserahkan kepada murtahin (penerima barang jaminan) atau kreditur. Dalam fatwa ini disimpulkan beberapa kesimpulan menurut Wangsawidjaja Z., dalam kaitan dengan jaminan pokok merupakan keyakinan bank terhadap kemampuan nasabah; agunan adalah jaminan tambahan, tetapi tidak identik dengan agunan tambahan, fatwa ini menegaskan barang dapat dijadikan jaminan utang, hanya saja jenis barang dan bentuk pengikat barang sebagai jaminan hutang tidak digambarkan terperinci. Wangsawidjaja Z, Pembiayaan Bank Syariah, (Jakarta: Gramedia Pustaka Utama, 2012), hal. 298.
} 
ada dalil pokok yang mendasari hal tersebut, yaitu: Pertama, kaidah dalam fiqh muamalat yang menyebutkan "hukum asal bagi muamalat ialah semua perbuatan diperbolehkan, kecuali ada dalil yang melarangnya". ${ }^{23} \mathrm{Kedua}$, hadis Nabi "Anda lebih tau tentang dunia anda". ${ }^{24}$

Di samping itu, dalam kaidah-kaidah fikih juga dikenal kaidah "al-adah al-muhakamah" yaitu adat dapat dijadikan (pertimbangan dalam penetapan) hukum, atau umumnya disebut dengan kaidah al-urf. ${ }^{25}$ Dalam pemaknaan kaidah ini, hukum jaminan dan perikatannya yang tidak diatur secara tegas oleh Islam berlaku ketentuan kaidah tersebut, dianggap sebagai bagian dari al-adah. Selama al-adah ini tidak bertentangan dengan patokan "mengharamkan yang halal, dan menghalalkan yang haram", maka penerapan jaminan ini tidak dapat dibenarkan dalam konteks hukum Islam. Padangannya dilihat jauh lebih flexible, dimana penekanan pada pembentukan suatu hukum harus pula melihat perubahan masyarakat dalam perubahan adat.

Ditambah lagi bank syariah sebagai lembaga intermediasi melihat meski kedudukan nasabah dan bank pada dasarnya merupakan hubungan kemitraan, dana yang digunakan oleh bank merupakan dana dari masyarakat (pihak ketiga/orang yang menabung), sehingga bank memiliki tanggung jawab kepada pihak ketiga untuk menjamin keamanan atas simpanan tersebut di bank syariah. Terlebih lagi, jika melihat track record keberadan bank syariah yang masih dianggap baru di dunia perbankan selalu memilik resiko, maka bank diharuskan meminimalisir kemunculan resiko tersebut. ${ }^{26}$ Dengan demikian, pembebanan agunan dalam pembiayaan syariah ini pada dasarnya merupakan realiasasi dari prinsip-prinsip pengelolaan bank Syariah berupa prinsip kehati-hatian, di samping prinsip lain yang diakui seperti prinsip kepercayaan, prinsip mengenal nasabah, dan prinsip kerahasiaan. ${ }^{27}$

Pada praktik bank syariah, ketentuan pengikat pada jaminan/agunan ini masih menggunakan ketentuan yang sama dengan yang dipraktikan dalam bank

23 Lihat Ibnu Taimiyah, Al-Qawa'id al-Nuraniyah al-Fiqhiyah, Juz II, (Riyadah: Maktabah al-Ruysd, 1422H/2001M), hal. 306.

${ }^{24}$ Nourouzaman Shiddiqi, Fiqh Indonesia: Penggagas dan Gagasannya, (Yogyakarta: Pustaka Pelajar, 1997), hal. 78.

25 A. Djazuli, Kaidah-Kaidah Fikih: Kaidah-Kaidah Hukum Islam dalam Menyelesaikan Masalah-Masalah yang Praktis, (Jakarta: Kencana, 2006), hal. 9.

${ }^{26}$ Terbukti jika melihat data statistik perbankan Indonesia (SPI) yang dikeluarkan OJK per Agustus 2015, aset bank umum tercatat senilai Rp 6.010,747 triliun. Sementara aset aset bank umum syariah dan unit usaha syariah senilai Rp 273,494 triliun atau 4,6\% dibandingkan total aset bank umum. Industri perbankan syariah mencatat tingkat pembiayaan bermasalah (non performing finance/NPF) sebesar 4,6\% pada kuartal II-2015. Angka tersebut jauh di atas kredit bermasalah perbankan konvensional di level 2,46\% pada periode yang sama. Per Agustus 2015 lalu pangsa pasar perbankan syariah masih sekitar 4,7\% atau di bawah $5 \%$ sehingga disebut 5\% trap. http://www.bisnis.com, akses tanggal 21 November 2015. Sekretaris Jenderal Asosiasi Bank Syariah Indonesia (Asbisindo) Achmad K Permana mengatakan, ada beberapa faktor yang menyebabkan NPF industri perbankan syariah meningkat. Hal ini disebabkan under control costumer, size perbankan syariah yang masih kecil, ketika ada satu nasabah yang jatuh maka akan mempengaruhi secara keseluruhan performance bank tersebut. Akses dalam <http://www.republika.co.id/berita/ekonomi>, akses tanggal 21 November 2015.

27 Abdul Ghafur Anshori, Penyelesaian Sengketa Perbankan Syariah, (Yogyakarta: Gadjah Mada University Press, 2010), hal.21. 
konvensional. Hal ini dikarenakan belum adanya ketentuan khusus atau fatwa DSN yang mengatur akan hal tersebut. Jika merujuk pada pemaknaan UU No. 21 Tahun 2008 tetang Perbankan Syariah sebagai lex specialis derogat legi generalis, maka setiap peraturan lain yang belum diatur dalam undang-undang perbankan syariah juga berlaku bagi praktik perbankan di Indonesia. Maka, ketentuan penggolangan jaminan ${ }^{28}$ hingga pengikat jaminan ${ }^{29}$ dalam bank syariah juga menggunakan dasar hukum perundang-undangan yang berlaku di bank konvensional.

Fungsi jaminan pembiayaan berupa watak, kemampuan dan prospek usaha yang dimiliki oleh debitur merupakan jaminan immateril berfungsi sebagai first way out, diharapkan pengelola dapat memperoleh pendapatan guna memenuhi pembiayaannya. Sedangkan fungsi jaminan pembiayaan berupa agunan bersifat materil sebagai second way out ketika debitur gagal (wanprestasi) atau macet dalam pelunasannya. ${ }^{30}$ Oleh karena itu, dalam praktik

${ }^{28}$ Jaminan dalam hukum perdata di Indonesia terbagi atas dua golongan, yaitu jaminan perorangan dan jaminan kebendaan. Jaminan kebendaan ini menurut sifatnya terbagi atas jaminan benda berwujud (berupa benda tidak bergerak dan bergerak), dan jaminan dengan benda tak berwujud (berupa hak tagih/cessie). Lihat Herowati Poesoko, Dinamika Parate Ekxecutie Objek Hak Tanggungan, (Yogyakarta: Aswaja Pressindo, 2013), hal. 26-27. Jaminan yang dapat dijadikan agunan kredit diatur dalam PBI No. 9/PBI/2007 merupakan aset sebagaimana tersebut yakni: Bangunan, Tanah, Kendaraan Bermotor, mesin pabrik, surat berharga saham, pesawat udara/kapal. Khusus untuk emas, bank konvensional tidak mengatur adanya penggunaan emas sebagai agunan bank, tetapi dalam bank syariah hal ini diakui sebagaimana merujuk pada Fatwa DSN No. 26/DSN-MUI/III/2002 tentang Rahn Emas, dan SE BI No.14/7/DPBS Tahun 2012.

29 Dalam hukum perdata di Indonesia, jaminan yang bersifat kebendaan dapat dikenakan pengikat berupa hak tanggungan untuk tanah sesuai ketentuan UU No. 4 tahun 1996 tentang Hak Tanggungan, Gadai, Fidusia berdasarkan UU No. 42 Tahun 1999 tentang Jaminan Fidusia, dan Hipotik.

${ }^{30}$ Wangsawidjaja Z., Pembiayaan Bank Syariah, (Jakarta: Gramedia Pustaka Utama, 2012), hal. 290-291. Catatan penting dalam keberadaan agunan sebagai jaminan tambahan di bank syariah ini tidak dapat dilihat seolah sama dengan praktik yang dilakukan di bank konvensional. Dalam praktik bank syariah, jaminan ini diharuskan, tetapi jika terjadi kemacetan (wanprestasi) dalam pembayaran pembiayaan, maka bank harus melihat lebih dahulu alasan ketidaksanggupan pembayaran pembiayaan ini. Bank syariah umumnya akan melihat ada tidaknya itikad baik perusahaan peminjam dana, untuk mementukan faktor kemacetan ini dilakukan atas dasar kesalah apa yang dilakukan. Kemudian, bank akan melihat apakah kondisi perusahaan termasuk good will company untuk menentukan penyelesaian keredit macet tersebut. Umumnya, jika perusahaan berada dalam good will company, maka bank dapat memberikan tolenrasi pembayaran, melalui di antaranya: Pertama, restrukturisasi pembiayaan bermasalah di bank syariah dengan cara: 1) Penataan kembali (restructuring), terdapat tiga upaya, yaitu: penambahan dana (suplesi), novasi perjanjian, pembaharuan pembiayaan. 2) Penjadwalan kembali berdasarkan Fatwa DSN No. 48/II/2005 tentang Penjadwalan Kembali Tagihan Murabahah. 3) Melalui persyaratan kembali (reconditioning), bisa juga dilakukan dengan melakukan konversi akad seperti dalam Fatwa DSN No. 49/DSN-MUI/II/2005 tentang Konversi Akad Murabahah, dari murabahah menjadi ijarah muntahiyah bit tamlik, mudharabah, dan musyarakah. 4) Bantuan Manajemen jika permasalahan timbul karena kesalahan manajemen. Kedua, Melalui jasa collection agent.Ketiga, Penyelesiaan melalui jaminan (Eksekusi) penyelesaian melalui jaminan dan mengacu pada Fatwa DSN No. 47/DSNMUI/II/2005 tentang Penyelesaian Piutang Murabahah Bagi Nasabah Tidak Mampu Membayar dan Fatw DSN No. 25/DSN-MUI/2002 tentang Lelang/Penjualan Marhun. 
perbankan syariah praktik Kredit Tanpa Agunan (KTA) sebagaimana banyak digunakan dalam Bank Konvensional tidak begitu banyak, bahkan masih belum ditemukan fatwa yang mengatur. Adanya praktik pembiayaan dalam agunan ini umum dilakukan dengan akad qordul hasan yang prinsipnya untuk saling membantu.

Hal ini berbeda dengan praktik KTA yang banyak dilakukan di bank konvensional. Praktik kredit tanpa agunan (KTA) yang dilakukan oleh bankbank konvensional ini seharusnya perlu diperjelas ke pada kreditur. Padahal jika kita melihat konsepsi dasarnya, penawaran dalam bentuk KTA yang pernah booming tahun 2012 lalu ini seakan menjadi hal yang ambigu mengingat Pasal 1131 KUHPer dengan tegas menentukan bahwa Seluruh harta benda seseorang baik yang telah ada sekarang maupun yang akan datang, baik benda bergerak maupun tidak bergerak, menjadi jaminan bagi seluruh perikatannya.

Pada perkembangannya, praktik semacam KTA di bank syariah juga mulai marak terjadi. Hal ini dikarenakan klaim dari berbagai pihak yang menganggap bank syariah terlalu correteral minded. Pasalnya, nasabah unbankable karena faktor tidak adanya jaminan umumnya akan lebih memilih ke BMT di bandingkan ke bank syariah yang mewajibkan adanya agunan tersebut. Pemerintah saat ini mulai menekan agar bank-bank syariah mulai lebih mempertimbangkan pembiayaan kredit tanpa agunan untuk peningkatan di sektor UMKM, khususnya ketika membutuhkan fresh money. Hanya saja, hingga saat ini ketentuan fatwa yang spesifik mengatur atas kebutuhan tersebut masih belum diputuskan. Berdasarkan berberapa penelusuran penulis, pada dasarnya bentuk pembiayaan tanpa agunan di bank syariah sudah banyak dipraktikan, di antaranya seperti: BNI Syari'ah dengan Hasanah Card; BJB Syariah dengan produk pembiayaan serbaguna (IB Maslahah); Pembiayaan multijasa Bank Victoria Syariah; Warung Mikro, pembiayaan umroh, BSM Implan dari Bank Syariah Mandiri.

\section{Penutup}

Berdasarkan uraian di atas, makan dapat disimpulkan bahwa pada dasarnya jika merlihat dapat pembentukan norma, terdapat pergeseran norma dimana agunan dalam Pasal 8 UU No. 10 Tahun 1998 tidak disebutkan secara tegas, tetapi dinyatakan tersirat dalam penjelasan pasal. Penjelasan pasal tersebut jelas menunjukan kedudukan jaminan sebagai faktor terpenting dan harus ada sebagaimana dipahami dalam Pasal 1135 KUHPer, yang kemudian dijabarkan lebih lanjut dengan agunan pokok ataupun agunan tambahan.

Berbeda dengan ketentuan Pasal 23 UU No. 21 Tahun 2008 yang tegas menyebutkan adanya norma agunan tersebut. Hanya saja prinsip dari alasan keberadaan kewajiban agunan dalam perbankan syariah ini tidak mengadopsi konsepsi sebagaimana dalam konvensional. Hal ini muncul lebih dikarenakan melihat adanya prinsip rahn dan kafalah dalam Islam, kaidah usuliyah-fiqhiyah dan kaidah al-urf. Disamping itu, Bank Syariah lebih melihat pada keberadaan dana yang disalurkan merupakan dana masyarakat yang harus dikeluarkan secara hati-hati dengam pertimbangan resiko dan moral hazard, sehingga kebutuhan akan agunan ini menjadi salah satu dasar pemberian pembiayaan. 


\section{Daftar Pustaka}

\section{Buku-Buku}

Anshori, Abdul Ghafur, Penyelesaian Sengketa Perbankan Syariah, Yogyakarta: Gadjah Mada University Press, 2010.

----------, Pembentukan Bank Syariah Melalui Akuisisi dan Konversi: Pendekatan Hukum Positif dan Hukum Islam, Yogyakarta: UII Perss, 2010.

Antonio, Muhammad Syafi'i, Bank Syariah: Dari Teori ke Praktik, Jakarta: Gema Insani, 2001.

Dewi, Ni Made Trisna, "Tanggung Jawab Debitur Terhadap Musnahnya Benda Jaminan Fidusia dalam Perjanjian Kredit Bank", Tesis, Program Pascasarjana Universitas Udayana, Denpasar, 2011.

Djazuli, A., Kaidah-Kaidah Fikih: Kaidah-Kaidah Hukum Islam dalam Menyelesaikan Masalah-Masalah yang Praktis, Jakarta: Kencana, 2006.

Fuadi, Munir, Hukum Jaminan Hutang, Jakarta: Erlangga, 2013.

Jundian, Pengaturan Hukum Perbankan Syariah di Indonesia, Malang: UINMalang Press, 2009

Mertokusumo, Sudikno, Penemuan Hukum: Sebuah Pengantar, Yogyakarta: Liberty, 2004.

Mudjieb, M. Abdul, Kamus Fiqh, Jakarta: Pustaka Firasu, 1994.

Murti, Indah Antari, "Perjanjian Kredit dengan Jaminan Fidusia Atas Kendaraan Bermotor Yang Dijual Pada Pihak Ketiga Pada PT. Bank Danamon (Persero) Tbk Unit DSP Pracimantoro Wonogiri", Tesis, Program Studi Magister Kenotariatan, Universita Diponogoro Semarang, 2010.

Poesoko, Herowati, Dinamika Parate Ekxecutie Objek Hak Tanggungan, Yogyakarta: Aswaja Pressindo, 2013.

Shiddiqi, Nourouzaman, Fiqh Indonesia: Penggagas dan Gagasannya, Yogyakarta: Pustaka Pelajar, 1997.

Soehino, Hukum Tatanegara: Teknik Perundang-Undangan, Yogyakarta: Liberty, 1996.

Suhendi, Hendi, Fiqh Muamalah, Jakarta: RajaGrafindo Persada, 2014.

Supramono, Gatot, Perbankan dan Masalah Kredit: Suatu Tinjauan di Bidang Yuridis, Jakarta: Renika Cipta, 2009.

Taimiyah, Ibnu, Al-Qawa'id al-Nuraniyah al-Fiqhiyah, Juz II, Riyadah: Maktabah al-Ruysd, 1422H/2001M.

Usman, Achmadi, Aspek-aspek Hukum Perbankan di Indonesia, PT. Gramedia Pustaka Utama: Jakarta, 2001.

Z., A. Wangsawidjaja, Pembiayaan Bank Syariah, Jakarta: Gramedia Pustaka Utama, 2012.

\section{Peraturan Perundangan-Undangan}

Kitab Undang-Undang Hukum Perdata

Undang-Undang Nomor 4 Tahun 1996 tentang Hak Tanggungan. 
Undang-Undang Nomor 10 Tahun 1998 tentang Perbankan.

Undang-Undang Nomor 42 Tahun 1999 tentang Jaminan Fidusia

Undang-Undang Nomor23 Tahun 1999 tentang Bank Indonesia.

Undang-Undang Nomor 40 Tahun 2004 tentang Pembentukan Peraturan Perundang-Undangan

Undang-Undang Nomor 21 tahun 2008 tentang Perbankan Syariah.

Undang-Undang Nomor 12 Tahun 2011 tentang Pembentukan Peraturan Perundangan-Undangan

\section{Sumber Lainnya}

Fatwa DSN No. 11/DSN-MUI/VI/2000 tentang Kafalah,

Fatwa DSN No. 26/DSN-MUI/III/2002 tentang Rahn Emas,

Fatwa DSN No. 25/DSN-MUI/2002 tentang Lelang/Penjualan Marhun.

Fatwa DSN No. 48/II/2005 tentang Penjadwalan Kembali Tagihan Murabahah.

Fatwa DSN No. 49/DSN-MUI/II/2005 tentang Konversi Akad Murabahah,

Fatwa DSN No. 47/DSN-MUI/II/2005 tentang Penyelesaian Piutang Murabahah Bagi Nasabah Tidak Mampu Membayar

Fatwa DSN No. 68/DSN-MUI/III/2008 tentang Rahn Tasjily

Fatwa DSN No. 74/DSN-MUI/I/2009 tentang Penjaminan Syariah.

Fatwa DSN No. 92/DSN-MUI/IV/2014 tentang Pembiayaan yang Disertai Rahn (Al-Tamwil Al-Mautsuq Bi Al-Rahn)

Pandomo, Agus, "Diktat Kuliah: Sistem Hukum Lembaga Keuangan Konvensional Bank dan Non Bank Jilid I dan II", Program Studi Hukum Bisnis Syariah, UIN Sunan Kalijaga Yogyakarta Tahun 2016.

Www.republika.co.id/berita/ekonomi/syariah-ekonomi/15/09/08/nud0fx254npf-bank-syariah-gede-bukan-karena-kredit-macet, akses tanggal 21 November 2015.

Www.bisnis.com, akses tanggal 21 November 2015. 